\title{
Public Policy and Recognition of Foreign Divorces: ZHANG V LIN AND MARZARA V MARZARA
}

\author{
GERALD B ROBERTSON*
}

Two recent cases — one from Alberta and the other from British Columbia — deal with the power of a Canadian court to refuse recognition of a foreign divorce on grounds of public policy. As is the case with foreign judgments generally, ${ }^{1}$ a foreign divorce that would otherwise be valid and enforceable in Canada will be denied recognition if its enforcement would be contrary to fundamental Canadian public policy. ${ }^{2}$ While the existence of this principle is well-established, its scope is quite narrow and it is rarely applied. Hence, it is interesting that in both cases discussed in this case comment, the public policy defence was successfully invoked to defeat recognition of the foreign divorce.

This case comment describes the circumstances which gave rise to the application of the public policy defence in these two cases, and then discusses whether its application was appropriate.

\section{ZHANG V LIN}

The central issue in Zhang $v \operatorname{Lin}^{3}$ was the recognition of a Texas divorce. The parties were married in China and subsequently moved to Alberta, where they lived together for approximately 14 years. ${ }^{4}$ In February 2008, the husband moved to Texas at the request of his employer. ${ }^{5}$ Approximately six months later he commenced divorce proceedings in Texas, and a divorce was subsequently granted. ${ }^{6}$ The judgment dealt with the division of matrimonial property, but made no provision for spousal support or for support for the parties' 22-yearold son (who was attending university in Alberta). ${ }^{7}$

The wife subsequently commenced proceedings in Alberta, claiming support for herself and her son. ${ }^{8}$ However, she faced a jurisdictional hurdle: only the court which grants a divorce has jurisdiction to vary corollary relief. ${ }^{9}$ In other words, if the Alberta Court were

QC, LLB, LLM, Professor of Law, University of Alberta.

See Beals v Saldanha, 2003 SCC 72, [2003] 3 SCR 416 [Beals]; Janet Walker \& Jean-Gabriel Castel, Canadian Conflict of Laws, 6th ed, vol 1, loose-leaf (Markham, Ont: LexisNexis Canada, 2005) at paras 4.3, 14.8.

The leading case is Powell v Cockburn, [1977] 2 SCR 218. See generally Walker \& Castel, ibid, vol 2 at para 17.2.

Zhang v Lin, 2010 ABQB 420, 500 AR 357.

Ibid at para 2.

Ibid at para 19.

Ibid at paras 20, 28. The basis for the Texas Court's exercise of jurisdiction was the husband's six months' residence in Texas prior to the commencement of the divorce proceedings. But, in fact, the husband's residence in Texas was a few days short of six months, which he disclosed in his application to the Texas Court. The Alberta Court held that in view of this disclosure by the husband, there was no fraud going to the jurisdiction of the Texas Court so as to warrant nonrecognition of the divorce.

Ibid at paras 28, 73 .

8 Ibid at para 23. Although he filed a Statement of Defence, the husband was not present at the hearing, nor was he legally represented.

9 Rothgiesser v Rothgiesser (2000), 46 OR (3d) 577 (CA) at paras 28-29 [Rothgiesser]. Although the Court in Zhang $v$ Lin stated that this point "is not entirely free from doubt" (Zhang $v$ Lin, supra note 3 at para 69), it should be noted that the Rothgiesser decision has been followed by the Alberta Court of Appeal: see Harman v Harman, 2009 ABCA 410, 469 AR 247. It was also reaffirmed by 
to recognize the Texas divorce as valid, it would have no jurisdiction to hear the wife's application for spousal and child support.

The first issue which the Court dealt with was whether the Texas divorce came within Canadian rules for recognition of foreign divorces. These rules are both statutory and common law. ${ }^{10}$ In the present case, the statutory ground did not apply, because it requires either spouse to have been ordinarily resident in the foreign jurisdiction for at least one year immediately preceding the commencement of the proceedings for divorce. ${ }^{11}$ With respect to the common law rules of recognition, ${ }^{12}$ the Court concluded that the husband had not acquired a domicile of choice in Texas by the time he filed for divorce, because he did not have an intention to live there indefinitely. ${ }^{13}$ This finding of fact effectively meant that there was only one common law ground on which the Texas divorce could be recognized, namely, the real and substantial connection test.

Based on the decision of the House of Lords in Indyka $v$ Indyka, the real and substantial connection test dictates that our courts will recognize a foreign divorce if either spouse had a real and substantial connection with the foreign jurisdiction at the time the divorce proceedings were commenced. ${ }^{14}$ This test has been adopted in many other areas of the conflict of laws, including enforcement of foreign judgments, ${ }^{15}$ and service ex juris. ${ }^{16}$ The case law in all of these areas demonstrates that it is a relatively easy test to satisfy, and this is certainly borne out by the decision in Zhang $v$ Lin. The trial judge held that the husband had a real and substantial connection with Texas at the time the divorce proceedings were commenced (less than six months after moving there), because "he had chosen to move to that state, to live there, and to become employed there."17

The relationship between domicile and the real and substantial connection test is interesting here. According to the trial judge, the husband's intention to settle in Texas was not sufficiently permanent for him to acquire a domicile of choice there, but nonetheless it was sufficiently strong to establish a real and substantial connection with Texas. Indeed, the emphasis in the trial judge's reasoning on the husband's intention (rather than on the length

the Ontario Court of Appeal in Okmyansky v Okmyansky, 2007 ONCA 427, 86 OR (3d) 587. For other appellate decisions which have endorsed this principle, see Booker $v$ Leonard, 2007 NBCA 71, 321 NBR (2d) 340; Virani $v$ Virani, 2006 BCCA 63, 264 DLR (4th) 524. But see GM v MAF, [2003] RJQ 2516 at para 48 (CA).

See generally Walker \& Castel, supra note 1 , vol 2 at para 17.2.

Divorce Act, RSC 1985, c 3, (2d Supp), s 22(1).

These are preserved under the Divorce Act, ibid, s 22(3).

Zhang v Lin, supra note 3 at paras 50-52. In its discussion of domicile the Court relied heavily on the recent decision in Re Foote Estate, 2009 ABQB 654, 475 AR 273, aff'd sub nom Foote v Foote Estate, 2011 ABCA 1, 493 AR 354, leave to appeal to SCC refused 34136 (7 July 2011). For a discussion of the decision in Re Foote Estate see Gerald B Robertson, "The Law of Domicile: Re Foote Estate” (2010) 48:1 Alta L Rev 189.

14 (1967), [1969] 1 AC 33 (HL) at 105. It is noteworthy that only a few years after this decision, legislation was passed in England which abolished the real and substantial connection test as a ground for recognizing foreign divorces: see Recognition of Divorces and Legal Separations Act 1971 (UK), c 53 [now Family Law Act 1986 (UK), c 55].

15 See Morguard Investments Ltd v De Savoye, [1990] 3 SCR 1077 [Morguard]; Beals v Saldanha, supra note 1 .

16 In Alberta, the real and substantial connection test is now the sole basis for service ex juris, although many of the traditional grounds are preserved as situations where a real and substantial connection is presumed: see Alberta Rules of Court, Alta Reg 124/2010, r 11.25. Even prior to the new rules, the real and substantial connection test was the sole basis for jurisdiction, as a result of Morguard, supra note 15.

$17 \quad$ Zhang $v$ Lin, supra note 3 at para 60. 
of residence) suggests that the real and substantial connection may have been established almost as soon as the husband arrived in Texas. ${ }^{18}$ If that is the case, it highlights how easy it is to meet the threshold of the real and substantial connection test.

Despite the finding that the husband had a real and substantial connection with Texas at the time he filed for the divorce, the trial judge held that the Texas divorce should not be recognized in Alberta, because its implications offended fundamental public policy of Canada. ${ }^{19}$ Specifically, it failed to make provision for spousal support or for support of the parties' 22-year-old son. ${ }^{20}$ In her conclusion that the Texas judgment offended Canadian pubic policy, the trial judge referred to the following factors:

(1) The parties' family ties during the past decade were closest with Canada, and the effect of the Texas divorce was very different from a divorce in Canada.

(2) The importance of supporting adult children in divorce laws in Canada; it is "an important cultural value, and is connected, for example, to Canada’s policy on university funding and its taxation policy.”

(3) The support of former spouses is also an important component of Canada's divorce laws; it is a "well settled and important policy."21

In light of her conclusion that the Texas divorce offended Canadian public policy and should therefore not be recognized, the trial judge then ruled that the Court had jurisdiction to deal with the wife's action for divorce and corollary relief, including spousal and child support. $^{22}$

\section{MARZARA V MARZARA}

The reasoning in Zhang $v$ Lin with respect to the public policy defence was applied by the British Columbia Supreme Court in Marzara v Marzara. ${ }^{23}$ The parties were born and raised in Iran, and married there in $1980 .^{24}$ They immigrated to Canada in 1986, but separated in 2006, and shortly thereafter the wife commenced divorce proceedings in British Columbia. ${ }^{25}$ A few months later the husband applied for (and obtained) a divorce in Iran, which awarded the wife US\$1,500 in spousal support and \$30,000 in matrimonial property division. ${ }^{26}$ The evidence in the British Columbia proceedings was that the family assets were worth nearly $\$ 4$ million. ${ }^{27}$ The husband argued that a court in British Columbia did not have jurisdiction

Ibid at para 52.

Ibid at para 68. Although the forum was Alberta, the trial judge referred to the public policy of Canada rather than Alberta. In so doing she was correct, because recognition of divorces is a federal matter pursuant to the Divorce Act, supra note 11, s 22. Quaere whether Alberta and Canadian public policy are necessarily the same.

Zhang $v$ Lin, supra note 3 at para 70.

Ibid.

Ibid at para 72 .

2011 BCSC 408, [2011] BCJ no 579 (QL) [Marzara]. For later related proceedings see Marzara $v$ Marzara, 2011 BCSC 1142, [2011] BCJ no 1602 (QL).

Marzara, ibid at para 65.

Ibid at paras 19, 39, 43.

Ibid at para 67.

Ibid at para 297. 
to vary the judgment of the Iranian court with respect to corollary relief. ${ }^{28}$ However, the Court held that the Iranian divorce judgment offended fundamental public policy and therefore should not be recognized. ${ }^{29}$

As in Zhang $v$ Lin, the Court held that the divorce met the criteria for recognition based upon the real and substantial connection test, ${ }^{30}$ but that its recognition would offend fundamental public policy of Canada. ${ }^{31}$ The Court's decision with respect to public policy was based on two factors. First, it concluded that the Iranian award of \$1,500 in spousal support and \$30,000 in matrimonial property division “appears to be starkly in contrast with the policy reflected in our legislation and jurisprudence with respect to division of property and the support of former spouses." 32 Secondly, the Court concluded that the husband's sole purpose in commencing the proceedings in Iran was to ensure that the British Columbia Court would be deprived of jurisdiction to make orders with respect to spousal support and matrimonial property, and he did this "to avoid what would otherwise be his legal responsibilities." 33

\section{DISCUSSION}

Are Zhang $v$ Lin and Marzara consistent with existing case law on public policy and foreign divorces? That is a difficult question to answer, and is certainly open to differing opinions. On the one hand, the two decisions can be viewed as taking the public policy defence far beyond its normal limits. It is well-established that the defence applies only in the most exceptional of circumstances, ${ }^{34}$ where the application of the foreign law would be "contrary to the fundamental morality of the Canadian legal system." 35 It is very difficult to accept that this high threshold was met in either of the two cases under review. In particular, it is clear that the public policy defence should not be used simply because the foreign law is different from ours, even significantly different, ${ }^{36}$ because to do so may undermine the very policy reasons which inform the choice of law rules which dictate that foreign law should be applied. ${ }^{37}$ As the authors of the leading text on the conflict of laws in Canada point

Ibid at para 64, relying on Rothgiesser, supra note 9.

Zhang $v$ Lin, supra note 3 at para 77.

Ibid. This aspect of the decision may be questionable. It is well-established that regardless of how strong the parties' previous connection with the granting jurisdiction may have been, if they have lost that connection by the time the divorce proceedings are commenced (which is the relevant date for applying the test), the real and substantial connection test will not be met: see e.g. Keresztessy $v$ Keresztessy (1976), 14 OR (2d) 255 (H Ct J) [Keresztessy]. In Marzara, supra note 23, the husband's ownership of property in Iran may have tipped the balance in favour of his having a real and substantial connection with Iran despite his absence from the country.

Marzara, ibid at para 77.

Ibid.

Ibid at para 78 .

See Beals, supra note 1 at para 75; Walker \& Castel, supra note 1 at para 8.6.

Beals, ibid at para 72. Can the Canadian Charter of Rights and Freedoms, Part 1 of the Constitution Act, 1982, being Schedule B to the Canada Act 1982 (UK), 1982, c 11, be used as evidence of fundamental Canadian public policy? See Vladi $v$ Vladi (1987), 79 NSR (2d) 356 (SC (TD)).

See especially Beals, supra note 1, where it was held that the mere fact that the damages awarded in a Florida action were far greater than would have been awarded by a Canadian court did not justify using the public policy defence to refuse recognition and enforcement of the Florida judgment in Canada.

The same is true of a court characterizing its own law as procedural and hence applicable, even though the main issue is governed by foreign law: see e.g. Toronto-Dominion Bank v Martin Estate, [1985] 39 Sask R 60 (QB). 
out: "The fact that the lex fori on the same point differs from the foreign law is not a sufficient ground for denying recognition to the foreign claim. Fundamental values must be at stake."38

Justice Wildman of the Ontario Superior Court of Justice, expressed similar sentiments in a recent case involving the recognition of an Iranian divorce:

[I]t is not appropriate for this court to impose Canadian law on other jurisdictions. Our standards and divorce principles are irrelevant if the foreign court had jurisdiction to deal with the matter. As the Iranian divorce is valid for the reasons set out above, the Iranian decision regarding the support and property claims must also be respected by our court. 39

It is clear that in both cases under review there was a significant difference between the foreign law and Canadian law, in the sense that the outcome would have been very different if Canadian law had been applied in the original divorce proceedings. However, principles of comity require due deference to judgments of foreign courts, ${ }^{40}$ and it is only the most exceptional of circumstances that this principle of comity should yield to considerations of public policy. It is certainly arguable that in both decisions under review, the case for doing so was not made out.

On the other hand, the decisions in Zhang $v$ Lin and Marzara are perhaps not so surprising when one considers how the public policy defence has been applied in other family law cases. Although, in theory, the defence is subject to the same high threshold regardless of the legal context in which it arises, in practice there appears to be a much greater willingness to apply it in family law cases. Examples include refusing recognition of a Hungarian divorce because its procedure did not encourage reconciliation, ${ }^{41}$ refusing recognition of a German adoption by an 82-year-old man of his 43-year-old common law partner, ${ }^{42}$ refusing to apply the matrimonial property law of Iran because it was "archaic and repugnant to ideas of substantial justice," 43 and refusing recognition (by the English courts) of a same-sex marriage. ${ }^{44}$ Perhaps the explanation for this greater willingness to resort to the public policy defence in the family law context (compared to, for example, the commercial context) is that these cases may more readily be perceived as involving the very type of "moral" or "fundamental" value that lies at the heart of the defence.

Walker \& Castel, supra note 1 at para 8.6

Dashtarai v Shahrestani, [2006] OJ no 5367 (QL) at para 24 (SCJ). See also Sangi v Sangi, 2011

BCSC 523, [2011] BCJ no 779 (QL), where an Iranian separation agreement and divorce were found not to be contrary to public policy.

See especially Morguard, supra note 15.

Keresztessy, supra note 30.

Wende v Strachwitz Estate (Official Administrator of), [1998] 7 WWR 480 (BCSC).

Vladi $v$ Vladi, supra note 35 at para 31.

Wilkinson v Kitzinger (No 2), [2006] EWHC 2022, [2007] 1 FCR 183 (Fam Div). By contrast, the public policy defence could not be used by a Canadian court to refuse recognition of a foreign same-sex marriage, in view of the policy reflected in the Civil Marriage Act, SC 2005, c 33, and the decision in Reference re Same-Sex Marriage, 2004 SCC 79, [2004] 3 SCR 698. Indeed, it is possible that a Canadian court might use the public policy defence to refuse recognition of a foreign law which prohibits same-sex marriage. See the discussion in Martha Bailey, "Same-Sex Relationships Across Borders” (2004) 49:4 McGill LJ 1005. 
It should also be noted that in the past (particularly in the 1970s and 80s) some courts succeeded in avoiding the perceived "unfair" effects of a foreign divorce, not by resorting to the public policy defence, but rather by a strained interpretation of the real and substantial connection test. For example, in one Ontario case the Court held that there was no real and substantial connection with the foreign jurisdiction (Illinois) despite the wife having resided there for over three years immediately prior to her commencing the divorce proceedings. ${ }^{45}$ Likewise, there are cases in which residence in excess of one year prior to the commencement of the divorce proceedings has been held not to satisfy the real and substantial connection test. ${ }^{46}$ However, this type of result is much less likely to arise today, now that there has developed a well-established body of case law in various areas of the law indicating that the real and substantial connection test is a fairly easy one to meet. In the face of such case law, an overly demanding standard for the real and substantial connection test would be almost impossible to justify. The result is that we will likely continue to see cases such as Zhang $v$ Lin and Marzara in which, in the family law context, a court makes use of the public policy defence so as to avoid an outcome which it considers to be fundamentally unacceptable. 